\title{
The emptiness of exilic and early Persian Judah: A historical study
}

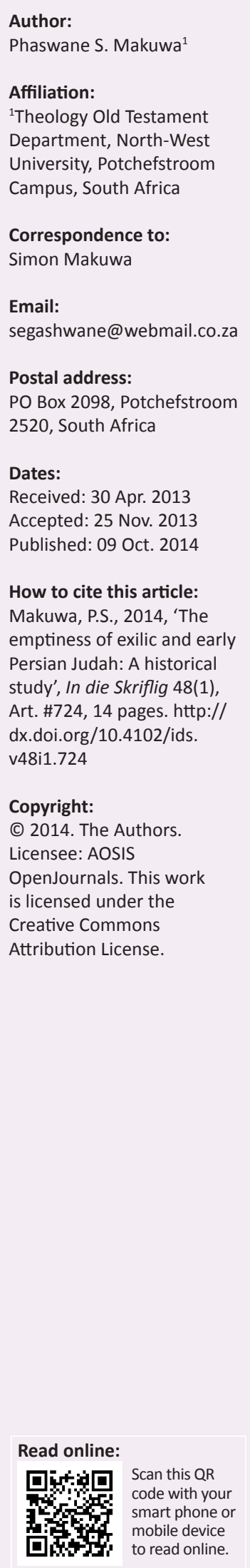

The exile of some Judeans under the Babylonian Empire from 597 to 582 BCE is perceived to have left the land of Judah without residents, according to some biblical passages. Historically and biblically, the land of Judah was not left empty, but some peasants remained behind when the important and legitimate elite was deported to Babylon. Some Judeans fled to Egypt and other neighbouring countries. Some of the elite were executed around 587-586 BCE. The legitimate monarchs of Judah were either murdered or deported to Babylon and Egypt. Gedaliah, of non-royal lineage, was appointed as a governor of Judah by Babylon, but he was assassinated. Subsequently, Judah was left without leadership or was probably incorporated into the Samaria provincial governance. The second rebellion of Zedekiah in 588 BCE resulted in the fall of Jerusalem (586 BCE), the capital city of Judah. The deported, murdered and dispersed elite left a legitimate leadership void, which translates into the exile of Judah. The cultic and civil services performed by the elite like festal ceremonies, daily sacrifices, trade, public administration, military and judiciary were halted by the Babylonian exile.Thus, Judah was exiled by Babylon at the termination of necessary services done in Jerusalem.

Die leegheid van ballingskap en die vroeë Persiese periode: 'n Historiese studie. Sommige Skrifgedeeltes dra daartoe by dat die indruk geskep word dat Juda sonder inwoners gelaat is na die ballingskap van die Judeërs in die tyd van die Neo-Babiloniese Ryk (597-582 v.C.). Histories beskou en op grond van inligting in die Ou Testament, was die land egter nie leeg nie. Sommige van die gewone mense het agtergebly toe die vernaamste mense en die leiers na Babel weggevoer is. Sommige Judeërs het na Egipte en ander lande gevlug. Sommige van hierdie vernames is in 587-586 v.C. tereggestel. Die wettige regeerders van Juda is óf tereggestel óf na Babilon en Egipte weggevoer. Gedalia, wat nie uit die koninklike geslag was nie, is as goewerneur aangestel, maar hy is vermoor. Gevolglik is Juda leierloos gelaat, of waarskynlik deur die Babiloniese owerheid by die Samaritaanse gebied ingelyf. Die tweede opstand van Sedekia in 588 v.C. het tot die val van Jerusalem, die hoofstad van Juda, in 586 v.C. gelei. Die verbanning en verstrooing van, asook die moord op die leiers en vernames het 'n leemte in regmatige leierskap gelaat wat Juda se ballingskap verklaar. Die kultiese en siviele dienste soos feestelike seremonies, daaglikse offers, handel en openbare administrasie wat deur die leiers verrig is sowel as die regstelsel en militêre eenheid is ook deur die Babiloniese ballingskap beëindig. Die ballingskap het dus eerder die beëindiging van noodsaaklike dienste geïmpliseer as die wegvoering van die totale bevolking .

\section{Introduction}

The concept of the exile of Judah to Babylon until 539 BCE has been perceived differently in biblical academic realms. The Bible marks the beginning of the exile of Judah from $586 \mathrm{BCE}$, after the defeat of King Zedekiah (cf. 2 Ki 25:21; 2 Chr 36:20; Jr 52:21; Lm 1:3). It appears that the concept of the emptiness of exilic Judah means that Judah was left devoid of residents. However, the contexts of all biblical expressions of the exile indicate that peasants were left behind when the elite was deported. The nation of Judah was not only defeated by Babylon, but earlier super powers wreaked havoc in Judah. The difference is that, prior to 586 BCE, the capital city, Jerusalem, was not affected due to the protective might of God (cf. 2 Ki 19:35-36). When Jerusalem was destroyed by Babylonians in 586 BCE, Judah was exiled due to the destruction of Jerusalem and the exile of the elite that was based in Jerusalem.

Leading to the destruction of Jerusalem by Babylon, the roles of Assyria and Egypt in subjecting Judah to foreign authorities should be historically studied in order to ultimately grasp the extent of the exile of Judah. 


\section{Problem statement}

Since prior to the end of the 20th century, some authors have not considered the impression of the emptiness of the land of Judah to be factual. These authors include Grabbe (2006), Sacchi (2000) and Barstad (1996). Grabbe (ibid:74) sees 'loose ends' and hints at the issue of the desolate land in the books of Ezra and Nehemiah. Grabbe (ibid:353) asserts that 'recent studies indicate that the bulk of the population [...] remained in Palestine'. The opinion of Sacchi (ibid:47) is that immigrants occupied the place of the exiles and life went on. The most relevant scholar is Barstad (ibid), who writes precisely about the emptiness of Judah, which he calls a myth, and posits:

While many scholars now admit that the most of the population apparently was left in Judah, they at the same time put forward the claim that this population possessed no culture, no religion, and no polity. (p. 41)

\section{Methodology}

Historical sources to be used include relevant extrabiblical literature to determine what it says about the exilic and immediate post-exilic experiences in Jerusalem. The destruction of the temple and walls and the burning of the gates of the city by Babylonians for political reasons were intended to instil or entrench obedience and prevent resistance. The goal of this article is to determine which aspects, religious or political, of Jewish life became weak or almost non-existent. The scanty information about the lifestyle of the Judeans who were left behind will be considered to determine if it does support the concept of the emptiness of Judah. Primarily, the approach of Miller and Hayes (1986) will be adopted in this research. They approach biblical history by studying primary sources of Bible writers and publications of other scholars such as Ahlström (1994) who considers theological, geographical and, to a certain extent, archaeological concepts.

\section{Successive destructions}

The territory of Judah did not suffer encroachments and destruction only under the Babylonians. Prior to the Babylonian exilic period, some preceding super powers negatively affected the land of Judah. The Judah of the time of the rise of Babylon was not the exact Judah of the united monarchy. Even though the territory of Benjamin became part of the land of Judah at the division of the monarchy, Judah proper was highly vulnerable. Up to the time that it was seized by Babylon, its borders often shifted because of foreign interference. Stern (2004) states:

The Assyrians also wrought havoc in Judah and their departure brought further devastation by the Egyptian army which seized control of parts of it and left many cities in ruins. (p. 274)

Wiseman (1996:98) indicates that in 701 BCE the Assyrian king, Sennacherib, advanced into Syria and conquered Sidon - and also managed to seize Lachish. Eventually, the Assyrian Empire collapsed in the course of the period 612-609 BCE. In 609 BCE, subsequent to the death of King Josiah and the exile of King Jehoahaz to Egypt, Judah became subject to Egypt.

\section{Fall of Assyria}

Kaiser (1998:357) dates the Assyrian hegemony from 745 BCE to $612 \mathrm{BCE}$, and calls it the Neo-Assyrian Empire. Assyria wielded power over Judah from during King Hezekiah's reign - specifically from 701 BCE when Assyria captured Lachish under the leadership of Sennacherib (Rogerson \& Davies 1989:153). The Assyrian super power certainly did not leave Judah unscathed. Its negative impact predisposed Judah to use alliance-forming defence tactics against Assyria. Isserlin (2001:89) explains that the alliances of Judah against Assyria was to no avail, as some cities of Judah were seized and Jerusalem had to pay high tribute to Assyria, even though it had not been seized. Scheffler (2001:121) dates the attempt to resist Assyria between 704 and 681 BCE during the reign of Hezekiah. Hezekiah took part in it, but the Assyrians quickly managed to withstand it in $701 \mathrm{BCE}$.

Betlyon (2005:5) says: 'Assyrian's stronghold on the lands of Mesopotamia and the Fertile Crescent came to an abrupt end in 612 B.C.E when a coalition of Medes and Babylonians captured Nineveh.' Edersheim (1995:964) specifies the names of the Median and Babylonian kings involved in the seizure of Nineveh as Kyaxares of Media and Nabopolassar of Babylon.

According to Herrmann (1981:266), in the battle of 609 BCE, Josiah was the King of Judah who had removed the gods of Assyria in places where they were kept in Israel and Judah. Herrmann (1981:266) continues to elucidate that Josiah wanted a reunion of Israel and Judah. Josiah wanted a complete fall of Assyria, which had exterminated Israel. Finegan (1999:252) indicates that Necho II meant to help the Assyrians to thwart the Neo-Babylonians. Necho II wished Egypt to succeed the Assyrian Empire to control Syria and Palestine. Wiseman (1996) describes the final fall of Assyria thus:

For 2 years the government under Ashur-uballit held out at Harran, but no help came from Egypt, Neco marching too late to prevent the city falling to the Babylonians and Scythians in 609 BC. Assyria ceased to exist and her territory was taken over by the Babylonians. (p. 99)

\section{Babylon versus Egypt over Judah}

Subsequent to the fall of Assyria, Babylon and Egypt were in a military and diplomatic battle to win control of Judah, until Judah became virtually non-existent or of such minor significance that that it was no longer desired as a buffer zone or for tributary reasons. Was it not for Egypt and Babylon's tussle for Judah, which lasted until 586 BCE when Babylon destroyed Jerusalem, the history of Judah might not have been as gruesome as it turned out to be, especially with regard to the deportations of people from Judah by Babylon. In fact, Judah suffered more than Egypt in the tussle between Babylon and Egypt (609-586 BCE) as Egypt was defeated only outside its borders. Egypt constantly withstood Babylonian attempts to penetrate its borders. 


\section{The opportunism of Egypt}

Edersheim (1995:959) explains that the fall of Assyria revived the innate dreams of Egypt, the enemy of Assyria at that time. As a result, Pharaoh Necho decided to challenge Assyria. Destroying the weak Assyria would have been ideal, but the matter of dealing with the rising Babylon was a matter of urgent attention. Edersheim (ibid:960) remarks on the possible subjugation of Assyria: 'In that case the expedition of Necho would have been designated "King of Assyria" as successor to that power.'

Kaiser (1998:388) explains that after the fall of Nineveh in 611 BCE, Egypt did not have the same respect for Assyria as in the past. In truth, Egypt wanted Assyria to fall. However, the rise of Babylon as an imposing super power forced Egypt to side with Assyria against Babylon. In supporting Assyria against Babylon, Egypt aimed to halt the rise of Babylon and not to restore Assyrian supremacy as such. Herrmann (1981:264) outlines the main motives of Egypt for engaging in a battle to support Assyria, namely to try and recover some lost territory, to control Syria and Palestine in order to protect Egypt from Assyria and its opponents, and to have buffer zones for protection against super powers.

Kaiser (1998:388) says that the battle of 609 BCE was unsuccessful for Egypt and Assyria. However, on its way back, Egypt managed to besiege Kadesh and gain control of part of Syria and Palestine. Furthermore, in Judah, Pharaoh Necho deposed and deported Jehoahaz, who had succeeded Josiah only three months earlier. The Pharaoh installed Eliakim and named him Jehoiakim. Henceforth, Judah paid tribute to Egypt.

The Pharaoh was not distressed that Assyria was defeated, despite their help, for Egypt had gained Kadesh and Judah. In a way, Egypt was still in the contest for supremacy in Syria and Palestine. Probably, even if Judah had not resisted Egypt en route to support Assyria against Babylon, Egypt would eventually have attempted to subject Judah under its authority. This would have conformed to its aspiration to control the Judean territory, which had been under Assyrian sway, for security and tributary reasons. Hence, in his retreat, Pharaoh Necho imposed tributary obligations on Judah.

\section{Josiah's family and Egypt}

Edersheim (1995:960) emphasises that Egypt was positioned against Assyria despite trying to help it against Babylon. Josiah attempted to thwart the Egyptians' offensive through Palestine to Babylon. It is said that Pharaoh Necho II advised Josiah to withdraw, but he refused, and thus Josiah was killed by the Egyptian troops near Megiddo (Beek 1963:123). Edersheim (ibid:961) states: 'Henceforth Judah was alternately vassal to Egypt or Babylon.'

Subsequent to Josiah's death, his sons were subjected to either Egypt or Babylon. Edersheim (1995:961) names Josiah's sons as Johanan, Eliakim (Jehoiakim), Shallum (Jehoahaz) and Mattaniah (Zedekiah). Each of the sons of Josiah that succeeded to the throne was appointed according to his loyalty to either Egypt or Babylon. Herrmann (1981:274) indicates that Pharaoh Necho II deposed and deported Jehoahaz to Egypt and replaced him with his older brother Eliakim, whose name he changed to Jehoiakim. Egypt had dominion over Judah, because they had killed Josiah and conquered the Benjamin area (Guillaume 2005:86).

\section{Babylonian power over Egypt}

The fact that Judah was a vassal state under the power of Egypt entailed that defeat of Egypt would also mean defeat of Judah. Because Egypt was still a force that could resist Babylon more than any other nation in Syro-Palestine, total independence of Egypt together with its influence even outside its borders was a clear threat to the rising Babylon.

Noth (1959:279) summarises the position of Egypt as: 'Egyptian rule did not last long. After the fall of Assyria the victorious Medes and Babylonians [...] shared the Assyrian booty'. According to Isserlin (2001:89), the fall of Assyria was precipitated by an internal contest for the position of king after the death of Ashurbanipal. Noth (ibid:280) continues: 'Egyptian Pharaoh Necho, was slain by the "king" Nebuchadnezzar of Babylon in the fourth year of the Judean king Jehoiakim [...] in 605 BCE.' The author explains that the Babylonian monarch usurped the Egyptian ruled land from the Euphrates River and that 'the State of Judah had to recognize the sovereignty of Nebuchadnezzar' (Noth ibid:280). Bruce (1997) elaborates that, following the defeat of Egypt by Babylon and Media:

... the king of Babylon had taken all his territory from the Wadi of Egypt to the Euphrates River. Assyria had disappeared for ever; the Babylonian empire now covered all the southern area of the former Assyrian empire while the Median Empire took over its northern provinces. (p. 81)

Miller and Hayes (1986:426) explain that Babylon was the greatest power compared to Assyria, Egypt, Media and Lydia. However, it was not able to wield power in the Near East like the Assyrians and the Persians had. Miller and Hayes (ibid) continue to point out the limiting factor as the Medes, who assisted Babylon to conquer Assyria by ruling:

... the highlands north and east of Mesopotamian plain. Most of the Fertile Crescent was in Babylonian hands, but the Medes largely controlled the eastern trade routes, forcing the Babylonians to turn their economic interests more to the west. (p. 426)

Moreover, Miller and Hayes (1986:427) indicate that the might of the Median power gave some Jews the impression that the Medes might oust the Babylonians from power. Such hopes were dashed by the Babylonian victory at Carchemish in $605 \mathrm{BCE}$.

\section{The victory at Carchemish}

The battle at Carchemish might have been waged over Assyrian territory in Palestine and Syria. Egypt was not being attacked - Egypt engaged in the battle for some 
motives. Coogan (2006:359) gives an indication that, in a way, Assyria and Egypt were united against Babylon, because the Assyrians are said to have also been defeated in the same battle. Coogan (2006:359) goes on to say that, after the victory of the Babylonians, they advanced against Egypt in order to restrict it within its borders and totally thrust it out of Palestine and Syria. However, Guillaume (2005:86) asserts that, after being defeated, Egypt managed to resist 'Babylonian invasions of its heartland until the Persian period'. Bruce (1997:79) states: 'So after one single battle all those states passed from the Egyptian into the Babylonian sphere of influence.' Bruce (ibid:79) further indicates that the Judean king of the time, Jehoiakim, 'formally submitted to him [Nebuchadnezzar]'. Edersheim (1995:965) emphasises that the Egyptian army was severely beaten and all former Assyrian colonies were taken by Babylon. Kaiser (1998:388) elaborates that Nebuchadnezzar defeated Egypt at Carchemish in 605 $\mathrm{BCE}$, but he was called back to Babylon, because his father had died.

The Carchemish battle had an impact on Judah, who was subjected to Babylon after the battle. Kaiser (1998) intimates:

Liberation from Egyptian bondage came in 605 BCE when Nebuchadnezzar drove the Egyptians out of Palestine, but little changed for Judah. Extradition from one form of slavery only meant its replacement with another form of slavery under Babylon. (p. 401)

Isserlin (2001:90-91) sums it up saying that'Syria and Palestine now fell, and Judah also submitted to Nebuchadnezzar (605-562 BCE).' Isserlin (2001:90-91) goes on to explain that the power of Egypt was not totally finished, because Egypt could defend its borders - even against Babylon - thus giving Judah false hope that Babylon could be overthrown or resisted by an alliance with Egypt. In the next section, the defensibility of Egypt will be evaluated.

\section{Egyptian resistance}

Pfeiffer (1962:13) posits his opinion of Egypt's strength as follows: 'The smaller states of Syria and Palestine were easy prey for Nebuchadnezzar. His real foe and potential rival was Egypt.' Pfeiffer (1962:13) continues to say that in Nebuchadnezzar's fourth year, Egypt and Babylon fought and there was no clear conquerer. Nebuchadnezzar returned to Babylon after being 'weakened' by Egypt. Furthermore, Pfeiffer (ibid:13) concludes that at that time, Babylon was the attacking nation and Egypt was defending itself, so the Babylonian troops were defeated. Egypt managed to withstand the Babylonian attack. Guillaume (2005:87) says that Babylon had to give up attempts to seize Egypt. Herrmann (1981:277) sums up: 'The king of Akkad and his host turned and went back to Babylon.'

It is clear that Egypt was stronger at home than Babylon. The Egyptian strength probably caused subjugated nations to hope that Egypt could deliver them from tributary burdens. The condition of Palestine was disadvantaged by the strength of Egypt, because, according to Guillaume (2005):
Once they saw that they could not conquer Egypt, the Babylonians did not invest in Palestine, but left the area desolate so that it could not be used against them. (p. 92)

The Egyptian resistance was instrumental in steering the history of Judah to an indeterminate state during the exilic period.

\section{Egyptian influence over Judah}

When Babylon defeated Egypt in 605 BCE, it also seized Judah. Guillaume (2005:86) claims: 'After Josiah's execution, Necho nominated Jehoahaz, only to replace him with Jehoiakim three months later.' Probably, Jehoahaz was used to influence Judah against Babylon, even when Babylon was appointing regent kings to serve on behalf of Jehoiachin.

\section{The last kings of Judah}

The last kings of Judah were all Josiah's sons and grandchildren. A fact worth mentioning is that the volatility of the situation during the rise of Babylon and the resistance of Egypt against Babylon caused great losses for the family of Josiah. Virtually all sons of Josiah, with the exception of Johanan (who either died whilst Josiah reigned or during the battle as his father did), and his grandson, Jehoiachin, had a stint on the throne. Sadly, they were all either killed in war or deported - thus, the legitimate Davidic dynasty was ended.

\section{Jehoahaz}

Baker (1996a) indicates that the book of Jeremiah identifies Jehoahaz as Shallum and that probably means that his royal name was Jehoahaz. He was the third son of Josiah, whose eldest brother, Johanan, was dead, whereas the second eldest brother, Eliakim, was still alive, but not sufficiently popular with the people of Jerusalem at that time to be appointed as king. Pfeiffer (1962:19) says that the people of Judah appointed Jehoahaz. However, Guillaume (2005:86) claims that Jehoahaz was nominated by the Egyptian Pharaoh, Necho, shortly after the death of King Josiah in 609 BCE. Perhaps his appointment as a vassal king was not imposed by the victorious Egyptian king, but some diplomacy was exercised in the process. He ruled for only three months, because the Egyptians deposed him when they came back from a war. He was replaced by the rightful heir to the throne, Eliakim, the second son of Josiah.

\footnotetext{
Jehoiakim

Jehoiakim's real name was Eliakim. Pharaoh Necho appointed him after he had deposed and deported Jehoahaz. It is not clear as to how Egypt knew that Eliakim was proEgypt. Edersheim (1995:263) reports that the king ruled for 11 years. Kaiser (1998:400) indicates that King Jehoiakim placed a heavy tax burden upon Judah. Kaiser (ibid:401) presents the king as the one who actually cut Jeremiah's scroll into pieces and threw them into the fire. The fact that Jehoiakim was appointed by Egypt as king of Judah caused the Babylonians to be harsh on Judah (Beek 1963:124). Herrmann (1981:277) explains that from $604 \mathrm{BCE}$, Jehoiakim was subjected to Babylon for about three years.
} 
When Egypt successfully resisted Babylon in the fourth year of Nebuchadnezzar, Jehoiakim sided with Egypt again and ceased to pay tribute to Babylon, according to Pfeiffer (1962:13). Pfeiffer continues to indicate that whilst Babylonian troops were recuperating, the pro-Egyptian group continued to consolidate themselves. Noth (1959:281) and Anstey (1973:223) report that, because of this rebellion, Nebuchadnezzar sent his army from the neighbouring nations, such as Edom, Moab and Ammon, to attack Judah in 602 BCE. Noth (ibid:281) further says that Jehoiakim either survived the attack or he resorted to a submissive attitude for another three years. Bruce (1997:79-80) reports that Jehoiakim tried to extend his borders by attacking weaker neighbouring nations that fought and defeated him and handed him to Babylon. Nebuchadnezzar favoured him, thinking that he had been fighting against Egypt and their supporters.

Guillaume (2005:89) says that in view of God's wondrous defeat of the army of Sennacherib in 701 BCE in favour of Judah, the support of Egypt and the belief that Zion could not be defeated, Jehoiakim was predisposed to rebel against Babylon - contrary to the advice of Jeremiah. Furthermore, Bruce (1997:79-80) mentions Egypt's severe defeat of Babylon in $601 \mathrm{BCE}$ - such that it took Babylonian troops about 18 months to recover. Jehoiakim and some other kings withheld their tributes. Kaiser (1998:402) says that, because of the rebellion of Jehoiakim, Babylon together with the Aramean, Moabite and Ammonite armies attacked Jerusalem in 597 BCE. Jehoiakim died during the battle, according to Coogan (2006:359) and Kaiser (ibid:402).

\section{Jehoiachin}

The rebellion that was the cause of the Babylonians' attack on Judah had been undertaken by Jehoiakim - the father of King Jehoiachin. Jehoiachin reigned for three months, just as Jehoahaz had. Kaiser (1998:402) elaborates that Jehoiachin was appointed as king in December 598 BCE and ruled until around March 597 BCE - Kaiser does not use the Judaic moon calendar. Sacchi (2000:47) indicates that since Jehoiachin's father, Jehoiakim, rebelled and died during the course of the war in 598 BCE, Nebuchadnezzar only arrested Jehoiachin without punishing him, as Jehoiachin's father had been responsible for the rebellion and not him. Kaiser (ibid:402) provides details saying: 'Jehoiachin, the queen mother, the princes and ten thousand leading citizens, smiths and craftsmen were taken along with servants and booty into captivity to Babylon.' The following comment by Edersheim (1995:967) illustrates the devastation of Nebuchadnezzar's actions, when he points out: 'All the treasures of the temple and the palace were carried away, the heavier furnishings of the sanctuary being cut in pieces.' Furthermore, Edersheim (1995:967) mentions that all the men that could fight in war or plan for battle were taken to Babylon in order to curtail any possibility of a war or rebellion.

Jehoiachin's life history does not indicate that he was restored to his position as king in Judah, but he was elevated to a position in Babylon higher than that of other kings that were arrested like him. Isserlin (2001:91) indicates that in Jehoiachin's stead, Mattaniah (Jehoiachin's uncle, also a son of Josiah) was appointed as a vassal king of Judah by Babylon. He was given the name Zedekiah by Nebuchadnezzar, King of Babylon.

\section{Zedekiah}

Babylon appointed a regent king, Zedekiah, to manage Babylonian affairs in Judah. The king was appointed in consideration of the Judean royal lineage. Herrmann (1981:280) indicates that Zedekiah succeeded his nephew, Jehoiachin. Sacchi (2000:47) explains that Jehoiachin did not yet have a son to succeed him, since he was only 18 years old. Herrmann (ibid:280) posits: 'Zedekiah was originally appointed as a man after Nebuchadnezzar's heart, but he did not prove to have this character.'

The influence of Egypt still hovered over Judeans and the Judeans themselves were not ideologically diluted and policed. Unfortunately, the king was not equipped with a military service or personnel to help him to enforce Babylonian control and to extinguish any uprising against Babylon in Judah. Pfeiffer (1962:22) intimates that Babylonians were unwise to deport all the elite, leaving behind 'inexperienced' persons to serve with the king. Zedekiah was probably expected to mysteriously keep Judah subject to Babylon.

Edersheim (1995:970) points out that Zedekiah reigned for 11 years. Kaiser (1998:402) highlights that Zedekiah ruled from 597 BCE to 587 BCE as a regent ruler. Like Jehoiakim, he was exposed to Egyptian influence. Pfeiffer (1962:22) comments: 'Egypt was constantly offering aid to encourage Judah to rebel against Babylon.'

Zedekiah led a divided people, with extreme difficulty. The majority were pro-Egyptian, although some were proBabylonian, according to Isserlin (2001:91). Isserlin continues to mention that in 594 or $593 \mathrm{BCE}$ an attempt to rebel against Babylon failed. Concerning this incidence, 'ambassadors from Edom, Moab, Ammon, Tyre and Sidon appeared at the court of Zedekiah - no doubt to deliberate about a combined movement against Babylonia' (Edersheim 1995:968). Kaiser (1998:404) says that this rebellion of Zedekiah was caused by pressure exerted on him by his anti-Babylonian, yet proEgyptian, government members. Zedekiah vacillated and yielded to pressure. Beek (1963:127) says that Babylonians asked Zedekiah to give an explanation regarding the objective of the meeting. In response Zedekiah sent ambassadors to appease the Babylonians, but Zedekiah was asked to account in person (Edersheim ibid:968). Eventually reconciliation was realised.

In 588 BCE, a new Pharaoh, Hophra, came into power in Egypt and he did not uphold the policy of non-interference (Sacchi 2000:47-48). With the involvement of Hophra, Zedekiah rebelled by not honouring his tributary requirements to Babylon (Provan, Long \& Longman 2003:280; Betlyon 2005:5). Betlyon (ibid:5) reports that, consequently, 'Judah faced the 
full onslaught of Neo-Babylonian arms'. Zedekiah trusted that Egypt would come to their aid, Herrmann (1981:282) attests. However, as Kaiser (1998:389) reports: 'But when Judah looked for help from Egypt, there was not much help there.' Kaiser continues to explain that in 588 BCE, Egypt managed to disturb Babylon for a while in an attempted fight, but the Pharaoh of the time, Apries, could not match the power of Babylon and he 'was driven back to Egypt and the siege of Jerusalem was again set in place' (Kaiser ibid:389). The war continued for three years, according to Herrmann (ibid:282).

A battle that lasts three years would normally have horrible consequences. Edersheim (1995:970) indicates that Judah was left on its own and exposed, with hunger added to their misery. He continues to say that in 11th year of Zedekiah, on the ninth day of the fourth month, Babylon 'gained possession of the northern suburb' (Edersheim ibid:970). Coogan (2006:364) points out that the city of Jerusalem was burnt, because of Zedekiah's rebellion. The Judean king was misled by neighbouring states (Coogan ibid:360-361), some of which (like Moab, Ammon and Edom) joined Nebuchadnezzar in destroying Jerusalem. Nevins (2006:15-16) postulates: 'The judgement of Nebuchadnezzar was clearly to terminate the Judean monarchy and obliterate Zedekiah's government.' Edersheim (ibid:970) reports that Zedekiah and his troops attempted to flee to the south, but that they were pursued and arrested. Though the king's daughters were freed, his sons were executed in his full view. Finally, his eyes were taken out, making his final sight to be the murder of his sons. Zedekiah was taken to Babylon where he died, according to (Edersheim ibid:970).

With Zedekiah's deportation, a second king of Judah was taken to Babylon - earlier, in 598 BCE, Jehoiachin had been taken to Babylon. Judah was a loser in the diplomatic schemes of the time.

\section{The fall of Jerusalem \\ Date}

Anstey (1973:226-227) and Jensen (1978:222) agree that the fall of Jerusalem occurred in 586 BCE. The siege that culminated in the fall of Jerusalem prevailed for more than two and a half years, according to Finegan (1999:259). Payne (1996:560) dates the seizure of Jerusalem to have occurred in 597 BCE and the destruction in 587 BCE. Baker (1996b:1268) explains that the battle began in $588 \mathrm{BCE}$ and was later on briefly suspended due to the intervention of Egyptian troops before it continued. Anstey (ibid:114) says that the fall of Jerusalem was hastened by a famine and it eventually occurred on the 9th day of the 4th month in the 11th year of Zedekiah's reign. Finegan (ibid:259) says that the exact day of the fall of Jerusalem was the 9th day of the 4th month in 586 BCE. Finegan goes on to say that, according to our calendar, the date would be 18 July 586 BCE. Therefore, if the siege began on 15 January 588 BCE and ended on 18 July 586 BCE, the actual duration of the siege was about two and a half years, as Finegan (ibid:259) indicates. Other details relating to the fall of Jerusalem will be considered in the sections on the aggravating factors and the severity of the fall after the next section on the significance of Jerusalem.

\section{The significance of Jerusalem}

Jerusalem was the capital city of Judah and from its origins in the time of King David, it was never intended as an optional dwelling place for the citizens of Judah, but as a capital city to unite the north and the south. Berquist (2008:44) says that Jerusalem was not regarded to be in either Judah or Israel and as such, it could be called the city of David. It represented the courage of David, since he seized it from the Jebusites. Turner (1973) posits:

The importance of Jerusalem to the nation and the world was not to be measured so much in its buildings and in its walls but rather in its spiritual significance. (p. 25)

It is against this background that the following statement is considered in this research: A country whose capital city is emptied of all authority by intruders is as good as empty.

Berquist (2008:47) guides Bible students to understand the significance of Jerusalem saying: 'Jerusalem seems not to be a space for living and residency, but a space for celebration, a place to visit for religious gatherings and a political spectacle.' Nevins (2006:15) substantiates: 'That Jerusalem went into exile does not mean the city was destroyed and completely emptied of inhabitants.' Nevins (ibid:15) regards this expression as a biblical hyperbole. Furthermore, Nevins (ibid:5) considers the records about the impact of the exile on Judah to be less carefully or technically constructed. He explains that the Babylonians would not burn the temple first and then loot it next - they would first plunder it and finally burn it, as opposed to the record of 2 Kings 25:8-17 that mentions the burning of the temple first.

Life would have been meaningless to Judah without any national identity that hinges on a specific government or leadership. Furthermore, the question would be if there could be a Judah without Jerusalem either to Judeans or to Bible readers. The fact that Jerusalem was, to many Judeans, a place worth their lives, underpins its significance. Jerusalem was the centre of Judah and it held Judah together. Without Jerusalem, Judah would be scattered and insecure. Virtually everything (cult, royalty, economy, courts, etc.) about Judah was based in Jerusalem. Without Jerusalem and all the leadership that was in Jerusalem, Judah was tantamount to insignificance.

\section{Severity of the fall}

Herrmann (1981) elaborates that after Zedekiah's rebellion, Nebuzaradan, the chief commander of Nebuchadnezzar's troops, was sent specifically to destroy the city of Jerusalem. Herrmann (ibid) posits:

The city was extensively burnt; gaps were made in the walls, depriving Jerusalem of its fortifications. Above all, the temple vessels were taken to Babylon, along with some of its structure: 
the iron pillars, the stands and the so-called iron sea, a great bowl containing water for purification. It is remarkable that the ark is not mentioned in this connection; we must assume that it too was either destroyed or taken away. (p. 284)

Edersheim (1995:971) explains that the temple and the palace were set alight - the entire city was 'reduced to ruins and ashes and the city ramparts were broken down'. Herrmann (1981) further explains that the state was completely disintegrated, even though some residue of citizens were dispersed and in danger of forfeiting their uniqueness or identity. Herrmann (ibid:285) intimates: 'One cannot describe vividly enough the totality of the catastrophe which had befallen Judah with the fall of Jerusalem.' Fohrer (1973) attempts to balance the report of the tragedy by pointing out that the city wall was not totally destroyed and that the city still had residents. However, he concedes, 'of course their condition was wretched' (Fohrer ibid:308).

Judah was left in a demoralised state, without any institution representing the identity of Judah. The capital city was not to serve as a centre of the state of Judah. Nothing was left of which Judah could pride itself.

\section{Aggravating factors}

Some of the factors that led to the gruesome fall of Jerusalem were internal and others were natural factors, which were not orchestrated, exploited or caused by the power of Babylon. These factors either caused Babylon to react harshly or advantaged Babylon during the siege.

However, Miller and Hayes (1986:417) indicate that, in the territory of Benjamin, extensive destruction was not experienced due to the probable capitulation of the entire Benjamin territory to Babylon.

The personality of Zedekiah was part of the problem. He was easily influenced or intimidated and a poor communicator, which made matters worse. Zedekiah lost the confidence of the Babylonians since he was unable to enforce Judah to pay tribute to Babylon. The major failure of Zedekiah was his inability to communicate with Babylonians about the volatility of the political atmosphere in Judah so that Babylon could put measures in place to curtail rumours of rebellion and deter it from actually realising. Apparently, Babylon could not understand that Zedekiah was put under pressure by pro-Egypt Judeans. Zedekiah could have informed Babylon about the situation, but he opted to agree with the pro-Egypt Judeans - probably because he had no security system to restrain rebellious tendencies in Judah.

Lipschits (2005:79) describes the defeat of Zedekiah when he and his supporters instigated a second rebellion against Babylon, saying: 'This time they were merciless and treated Zedekiah as one who had violated his personal oath of fealty to Nebuchadnezzar.' Zedekiah, who was the last son of Josiah, was taken out of Judah and with all his sons murdered, it meant the end of the legitimate dynasty of David, Lipschits (ibid:79) attests. The last king of Judah, King Zedekiah, died in Babylon.

In this process of harsh treatment unleashed against Judah, Nevins (2006:6) points out that the temple was partially destroyed by the Edomites. The Edomites became one of the external factors that made matters worse. Nevins (ibid:7) goes on to elaborate that it might have been the Edomites who burnt the temple after the Babylonians had left or even whilst the Babylonians were still in Jerusalem. They could also have received directives from Babylon to burn down the temple. Bruce (1997) says that the Edomites took for themselves the southern part of Judah, which was better known as the Negev. Bruce (ibid:84) postulates: 'Possibly the Chaldeans officially gave the Negev to Edom.' Babylon was not the only oppressor and destroyer of Judah. Edom in particular was working for the extermination of Judeans for purposes of gaining more land. Edom perhaps positioned itself as a trustworthy ally of Babylon with the motive of increasing its territory by taking part of the land of Judah.

Betlyon (2005:6) describes the long siege of Jerusalem, which lasted more than two years before $586 \mathrm{BCE}$, and states: 'Sites were abandoned because of war, disease, drought and starvation.' Unfortunately, nature did not favour Judah at all. The drought at the time of the siege could be seen as an ordeal brought on Judah by God, who had instructed the Judeans through prophets like Jeremiah to submit to Babylon. In a way, Zedekiah's rebellion under the influence of some Judeans was also rebellion against God and drought was the response of God. There was no way Judah could survive the aggravating circumstances that they brought upon themselves by their rebellion.

\section{Cultic and political conditions of Jerusalem}

The systematic destruction carried out by Nebuzaradan was not meant to be sheer demolition, destruction and punishment, but it was of political and cultic significance, intended to incapacitate Judah such that there would be no possibility of a rebellion ever again. Lipschits (2005:112) portrays the destruction as follows: 'The city was laid waste in a systematic and calculating manner designed to eradicate it as a political and religious center and it remained desolate and abandoned.' Commenting about the actual impact of the fall of Jerusalem, Bright (1972:343) says that the royal and temple institutions were hard hit and 'they would never be re-created in precisely the same form again'. Nevins (2006:16) argues that 'both text and tell when properly excavated agree that the destruction and deportations rendered a different reality in the land, one that was without monarchy and without Temple'.

The pride of the nation of Judah was the Jerusalem temple built by Solomon. The destruction of the temple was a cruel blow to Judah, because it was the place of their God, who was mightier than their kings were. Edersheim (1995) 
specifies the dates on which the destruction was completed as the ninth and tenth day of $\mathrm{Ab}$ in $586 \mathrm{BCE}$, which were to be commemorated, and posits the following:

All of any value in the Temple that could be removed, either whole or broken up, was taken to Babylon [...] the general population of Jerusalem and of Judah were carried into captivity. Only the poorest in the land were left to be husbandmen and vine-dressers. (p. 971)

Edersheim continues to tell that Seraiah, the high priest, and Zephaniah, the second priest, and 'three keepers of the doorchiefs of the Levites who kept watch at the three Temple gates were [...] executed' (Edersheim 1995:971). Noth (1959:286) says that the Ark might have been burnt and destroyed after Zedekiah's rebellion. The ultimate historical object of power, the Ark, had disappeared with all the significant things that it contained. Some cultic servants were exiled whilst others were executed. This blow put an end to normal and legitimate cultic services in Jerusalem. Miller and Hayes (1986:416) say that the repression of Judah's revolts and the demolition of the city of Jerusalem were 'severe cultural and theological shocks for Judean society'.

All that made Judah stand out amongst other nations was to no effect, and the power that had withstood the Assyrians was withheld by God in disapproval of various atrocities and idolatry. The entire existence of Judah had previously been in the hands of God - in political, economic and cultic spheres. When God forsook Judah, everything fell apart to the dismay of all Judeans. According to 2 Chronicles 36:15-17, God sent messengers to Judah, but they were disregarded and mocked. Ultimately, God's anger was kindled against them and God decided to hand them over to Babylon, for there was no more remedy for them.

\section{The situation of the population}

Bright (1972:344) intimates the following: 'Nebuchadnezzar's army left Judah a shambles [...] The population of the land was drained away.' Lipschits (2005:59) indicates that the population of the entire kingdom of Judah was about 110000 and only 10000 had been exiled with Jehoiachin. In 2 Kings 25:11-12 it is indicated that Nebuzaradan took the rest of the people who were in Jerusalem, excluding some poor persons. The words of Jeremiah 24:10 allude to the fact that, from the time of the exile of Jehoiachin, God warned that he would plaque Zedekiah and the remnant with famine. Lipschits (ibid:60) goes on to consider the quality of the people left in the land and cannot help but find justification for the analogy of good figs and bad figs expressed in Jeremiah 24 .

The notion of a total deportation is given attention by Bright (1972:343-344), who regards it to be wrong if it means that the land was left 'empty and void', but admits that 'the catastrophe was nevertheless appalling and one which signalled the disruption of Jewish life in Palestine'. Kaiser (1998:405) bluntly says: 'The Babylonians deported the rest of the people left in the city along with the deserters who had gone over to the king of Babylon.' However, the writer explains that the deportation did not result in resettlement of foreigners in the land of Judah and Jerusalem. From this point a new paragraph begins, but there should be no other changes, no bullets.

Different scholars present the condition of Jerusalem in different terms. Edersheim (1995) posits:

[T] he last remnants of Judah had gone from the land. The Davidic rule had passed away, so far as merely earthly power was concerned [...] But overall the city would be desolateness and the stillness. Yet was it stillness unto God. (p. 973)

Turner (1973:230) says: '[T]he "ghost city" welcomed returnees from Babylon.' To Berquist (2008:41), the city of Jerusalem was remarkably depopulated and Isserlin (2001:91) estimates: 'Most of the population - two-thirds perhaps - had perished in the war or were carried off into exile in Babylon.'

It is generally accepted that the population of Jerusalem in particular was not left the same by the attacks of Babylon, which were caused by the rebellions of the last few vassal kings of Judah. Total depopulation never happened, but the poor population that remained was left completely incapacitated to restore Judah to its reputation without the help of the deported population.

\section{Exilic Judah}

After the destruction of Jerusalem and the complete deportation or execution and flight of the elite of Judah, the time of the exile truly came into effect. It was clear that Judah could not be the same again as long as Babylon's sway prevailed.

\section{Judah's final recognition}

Prior to the destruction of Jerusalem and the massive deportation of the elite, Judah was a vassal state. However, Bruce (1997:86) points out: 'After he had punished Judah for its rebellion Nebuchadnezzar reduced its size and made it a province of his empire.' At that time, the Edomites occupied the southern part of Judah. Perhaps the Babylonian king reasoned that reducing Judah would help to manage it. However, Herrmann (1981:291) argues: 'There is no express mention anywhere that Judah was made a regular Babylonian province.' Herrmann (1981:291) proceeds to say that even Gedaliah was not appointed as a provincial governor. Miller and Hayes (1986:422) disagree that Judah became a province and, basing their opinion on a particular seal found in the Mizpah area, postulate that 'Gedaliah was king over a Judean kingdom centered at Mizpah, following the fall of Jerusalem in 586 BCE'.

Noth (1959) concurs with Bruce (1997:86) that it was after Zedekiah's rebellion that Judah became a province and explicates his convictions as follows:

Nebuchadnezzar now made an end of Judaean autonomy [...] But Nebuchadnezzar now did what he had failed to do 
in the year $598 \mathrm{BCE}$, he incorporated Judah in the provincial organization of the Neo-Babylonian Empire and eliminated the Davidian monarchy which had ruled in Jerusalem for about four centuries. (p. 286)

The new province or governance structure was to be based in Mizpah, and Gedaliah was to be the leader of this new governance establishment. Nevins (2006:19) says that Mizpah could have been chosen due to its peacefulness after the destruction of Jerusalem. With the assassination of Gedaliah later on, Judah lost its national or political status.

\section{Actual deportations and emigrations}

Some Judeans left Judah under duress, whilst others left voluntarily since the power of Egypt over Judah was replaced by that of Babylon. All those who relocated left a significant vacuum in Jerusalem.

The period called 'the exile' is a highly technical concept and difficult for Bible students to understand. Anstey (1973:222) posits: 'The date of the exile is the 3rd year of Jehoiakim [...] 605 BCE'. Guillaume (2005:91) claims: 'The destruction of Jerusalem marked the beginning of what Old Testament scholars commonly call the exilic period.' The exile of Judah to Babylon, according to Lamentations 1:3 and 2 Kings 25:21, and the exile of some persons from Jerusalem together with King Jehoiachin, according to 2 Kings 24:15-17, should be differentiated. After Jehoiachin had been taken to Babylon, Zedekiah was appointed king and palaces were not destroyed. However, after Zedekiah had been taken away, there was no more king and palaces, and the city wall was partially destroyed. Suffice it to say the exile era began with the total destruction of palaces and the temple in 586 BCE. These assertions are supported by Davies (2007:155) in his understanding of what historians mean by the 'exilic' era.

\section{Actual deportation numbers}

Three deportations are recognised to have happened under the auspices of Babylon. The first deportation occurred when Jehoiachin was deposed and exiled in 597 BCE. Bruce (1997) posits:

The city was taken on March, 597 BC, and Jehoiachin, with many members of the royal family and the leading statesmen and courtiers, was taken captive to Babylon. So too were many other members of the higher ranks of Judean society - three thousand in all. (p. 80)

Beek (1963:127) concurs with the qualitative definition of the class of people first deported and points out that such a deportation was meant to weaken Judah's militarily and incapacitate the possibility of national governance - even though the Davidic dynasty was honoured when Zedekiah (son of Josiah) was made a vassal king. Miller and Hayes (1986:419-420) contrast the record of the book of 2 Kings with the book of Jeremiah regarding the first deportation. Miller and Hayes (1986:419-420) point out that 2 Kings 24:14 reports that 10000 captives were carried away, and 2 Kings 24:16 reports that 7000 captives and 1000 craftsmen and smiths were deported in the eighth year of Nebuchadnezzar (2 Ki 24:12). Jeremiah 52:28 reports that 3023 Judeans were exiled in the seventh year of Nebuchadnezzar. Nevins (2006:5) supports the statement that 3023 Judeans were deported in the seventh year of Nebuchadnezzar. The passage in 2 Chronicles 36:910 only reports the exile of Jehoiachin and not the other captives. In fact, Jeremiah 37:1-2 only summarily indicates that Zedekiah was appointed to reign instead of Jehoiachin and not much else is said. Therefore, if Jeremiah had been in hiding due to the threats of Jehoiakim and was only freed during Zedekiah's reign after the first deportation, his account on the number of the first deportees may not be very reliable. A Bible writer who might have observed the actual arrival of the deportees in Babylon could have presented facts that are more credible. Thus, the summary of Jeremiah that reports only 3023 deportees might not have been the actual number, whereas a total of 10000 according to 2 Kings would be acceptable.

Roberts (2002:60) argues that proper historiography originated in Israel and not Mesopotamia or Egypt. The historiography referred to here should not mean that the Bible contains all history of Israel or Judah. Bullock (2003:97-98), in defining history, succinctly states: 'History is a human enterprise of chronologically selecting and recording events in time and space, and doing so interpretatively or with a particular perspective.' The writer (Bullock ibid) continues to indicate that unrefined facts are presented with their interpretation in the biblical record. The elements of selecting and interpreting are extremely critical in biblical records. If any historical gaps are found in the biblical discourse, they are deliberately made and may not be regarded as historical blind spots. All history in the Bible, including the history of Israel, might have been selected and accompanied by interpretations of some events. The book of Chronicles refers to the following historical sources: the records of Samuel, Nathan, Gad, Ahija, Iddo, the prophet Isaiah, the book of Kings of Israel and Judah and the annals of Jehu (1 Chr 29:29; 2 Chr 9:29; 13:22; 16:11; 20:34; 27:22; 32:32). The book of Chronicles implicitly concedes that it does not record some events or details that can be found in other sources, which are clearly indicated. In this case, the selection is not concealed, but declared.

The second deportation, according to Beek (1963:129) and Herrmann (1981:291), took place after Zedekiah's rebellion and during the fall of Jerusalem, when around 832 men were deported to Babylon. Bruce (1997:83-84) dates the second deportation to have occurred in August 587 BCE.

The third deportation occurred after Gedaliah had been assassinated. Herrmann (1981:291) dates the tragic event to have transpired in $582 \mathrm{BCE}$, when 745 Judeans were taken captive by Nebuzaradan, as instructed by Nebuchadnezzar. Miller and Hayes (1986:420) indicate that the book of Kings seems to be silent about the third deportation, whilst Jeremiah 52:30 accounts that 745 Judeans were deported in the 23rd year of Nebuchadnezzar, which is precisely the comprehension of Nevins (2006:5). 
Miller and Hayes (1986:420) indicate that the sum of the deportations was 4600 . This is calculated based on the first deportation being 3023 , the second deportation being 832 and the third deportation being 745 . This calculation is based on Jeremiah's calculated summary. The number that Jeremiah gives for first deportees is disputable, even biblically, as far as its source is concerned - whether it had been Jeremiah himself or his students or even admirers. If the numbers of the second and third deportations according to Jeremiah would be acceptable as 832 and 745 respectively, they add up to 1577 . This number of 1577 and the 10000 captives of the first deportation add up to 11577 deportees.

\section{Indefinite emigrations}

The population of Jerusalem was reduced by not only deportations, but also the emigrations of Judeans who might have fled in fear of punishment by the Babylonians. Lipschits (2005:105) states: 'The Benjaminites were joined by refugees who apparently had fled from Judah during the Babylonian siege of Jerusalem.' However, Lipschits (ibid:106) points out that some refugees 'were also in Moab, Ammon, Edom and in all the countries'. Bigger (1994:233) reckons that the Jewish community was 'dispersed very widely'.

Nobody can quantify the emigrations from Judah during the Babylonian Empire. Those who emigrated to safer places, like the Benjamin territory and other places outside Judah, were the residents of Jerusalem who were in fear of death at the hands of Chaldeans. The emigrations could have been more than the deportations in number, or vice versa. Subsequent to these emigrations, Judah was left with an incapacitated and dysfunctional capital city, Jerusalem.

\section{Socio-political status quo in Judah}

Babylon did not necessarily set out to destroy the cultic practices of Judeans. Their main objective was to keep Judah under control as a vassal state in order to receive tribute and to remain the predominant power or empire. The political systems and structures were the main target of the NeoBabylonian super power.

\section{Political status}

Bruce (1997:76) regards the death of King Josiah as 'the end of Judah's independence'. Sacchi (2000:49) identifies those who had been deported as 'the rich, the ruling class both in political and economic terms'. Miller and Hayes (1986:421) claim that the accurate particulars of the political position of Judah immediately after the devastation of Jerusalem are uncertain and controversial. Barstad (1996:68) poignantly asserts that the state of Judah was substituted with that of Babylon. Pfeiffer (1962:42) states that 'with the destruction of Jerusalem, Judah ceased to exist as a sovereign state'. It was better when it was under Gedaliah. However, Bruce (ibid:87) explains that around the time of the assassination of Gedaliah, all Judah, excluding the Negev, was reckoned with the province of Samaria and asserts that ' $[a] 11$ political activity in Judea ceased'. That was the real political emptiness of Judah.

\section{Social status}

What kind of social life did Judeans live without any governance for moral guidance? People probably, like the pre-monarchic era of the Judges, did as they pleased. The writer Soggin (1993:268) states: 'A very negative factor to set against that was the destruction of social and economic structures in which those who had benefitted could have expressed themselves and developed.'

Pfeiffer (1962:44) reports that, because of the Babylonian victory over Judah, most places remained unoccupied for a long time during the exile. The writer continues to explain that the Edomites and Arabians encroaching from the south took some places, and the Ammonites and various peoples from Trans-Jordan came to take as much land as they wanted. All these foreign tribes came much closer to the heart of the land of Judah. Noth (1959:291) says that the remnant population of Judah became mixed with the newly introduced elite from other places. Pfeiffer (ibid) portrays the dilution and decay of the Judeans as follows:

For fifty years after the destruction of Jerusalem, Judah was left to its own devices [...] the inhabitants of Judah - Jews, and nonJews - had adjusted to a new mode of life. (p. 45)

Pfeiffer (1962:44) presents these foreigners to have been dominant over the Judean remnant.

\section{Unknown lifestyle}

The lack of information about the kind of life in Judah during the exilic period is indicative of tremendous disruption of life in Judah. Davies (1999:77) postulates: 'We can in fact add very little to the meagre data we have concerning Judeans between Nebuchadnezzar and Cyrus.' Renkema (1998:108), in commenting on the book of Lamentations, expounds that captivity and slavery left the state of Judah to be bare, to such an extent that foreign troops walked about in Judah to enforce slavery. Furthermore, Renkema (ibid:109) intimates that the remnant could not execute their duties as in normal circumstances. Raabe (1995:22) dates the book of Obadiah to the 'early exilic period, ca. 585-555' and further presents the prophet to have been in Judah at that time (Raabe ibid:47). However, the book of Obadiah lacks information about the lifestyle of the remnant. The book of Obadiah (Ob 1-14) rather has Edomites as its addressees and not Judah at all. The book of Lamentations, except its lament expressions of the remnant, does not give basic information about the lifestyle of the remnant.

Concisely, Beek (1963:135) declares: 'The Babylonian exile ended the history of Judah and Jerusalem temporarily.' Kaiser (1998:422) says that virtually all the knowledge about Judeans at hand during the period of the exile concerns the deportees' departure, which resulted in a residential void in Judah. Kaiser (1998:422) emphasises that there are no details about what was happening in Judah during the exile.

The belief that life in Judah went on as normal during the exile lacks substantiation. Since there is nothing definite about a 
particular Judean lifestyle in Judah during the exilic period, the indefiniteness of the status quo borders the concept of the emptiness of Judah. The lifestyle of Judeans would consistently have to do with God or their religion, but the reforms, as documented in the books of Ezra and Nehemiah, do not portray any religious continuity. Of course, the mourning, as depicted in the book of Lamentations, cannot be a sign of religious continuity, since lament is largely emotional rather than religious and is naturally temporary and circumstantial.

\section{Perceptions of the exile}

Usually, the question is whether Judah was literally emptied of all residents or what the concept of Judah being exiled means. Studying the Bible writers' perceptions and that of the people that lived in and outside Judah during the exile allows for an interesting interpretation. Fohrer (1973:308) considers the historical thought paradigms of the Judeans who survived the exilic period inside and outside Judah. He concludes that some Judeans thought that the reforms of Josiah angered some gods - especially the gods that were destroyed and those whose shrines were destroyed - whilst others thought that the exile and destruction of the city was due to the judgement of God, who had been disobeyed by Judah. In particular, he (Fohrer ibid:309) states: 'Thus popular religion came to prevail with more Canaanite than Yahwistic features.' Sacchi (2000:53-54) claims that the remnant believed that God was present in the destroyed temple, protecting his people, whilst the exiles generally believed that the remnant was not under God's protection. Sacchi refers to Ezekiel 11:17, and 15:20 and verse 38 in order to accentuate the fact that 'the Glory of God had left the temple' (Sacchi ibid:53-54).

Nevins (2006:5) concludes that the problem is that the editors of the Bible could not work out conflicting ideas in doing their work of writing or copying. Nevins (referring to 2 Ki 25:12 and 21, which says: 'Thus Judah was exiled from its land') argues that this statement negates the earlier indication that not all of Judah was exiled. He (Nevins ibid) further claims:

The authors/editors of 2 Kings 25, writing probably at least a generation after these events had taken place, may have had to sift through conflicting accounts - and ideological issues were more important to them than documenting events in their precise historical sequence. (p. 16)

Barstad (1996:30), on the one hand, regards the books of Kings, Chronicles and Jeremiah as 'sources for the historian' regarding the 'the last days of Judah', but on the other hand (ibid:31) claims that these sources are written by Hebrews in their 'storytelling' approach and thus they are 'not an historical account of what actually happened in Judah'. Furthermore, Barstad (ibid:44) alleges the books of Ezra and Nehemiah to rather be 'religious and political propaganda than historical documents'. It would be difficult to uphold either the idea that says the Bible is an infallible historical book or the idea that the Bible contains no history at all. Klein (1979:23) believes that Deuteronomic writings were written during the exilic period and asserts: 'Its purpose was overwhelmingly didactic and theological; the author was not trying to present an objective narrative of the facts of history.' Gertz (2010:11-12), in comparing the history of Israel to that of Judah in the light of the disasters experienced, perceives that the prophecies of the Old Testament were theological efforts in reaction to disasters.

However, Bible writers show that Judah was not uninhabited during the course of the exile. Nevertheless, what was left in Jerusalem was not sheer desolation. The Bible writers did not write pure history, but they wrote about the fulfilment of theological possibilities should there be a need for an exile experience in order to curtail sin (Lv 26:40-42). The book of 2 Chronicles 36:21 refers to the Sabbath rest, which the land enjoyed, and the 70 years of exile that were completed. The concept of the land enjoying the Sabbath rest is derived directly from Leviticus 26:43. If the Bible writers chose to use the word 'enjoy' without reference to an earlier writing, they would have been clearly sarcastic, because there was nothing to enjoy and the writers of Lamentations were not in a joyful mood either. The issue of the 70 years of servitude is derived from Jeremiah $25: 11-12$ and $29: 10$, which is about a period of subjection of Judah to Babylon and ends at the time of the return. Nevertheless, Dillard (1987:301) presents two views about the beginning and end of the period. The first view would mark the beginning of the period as 605 $\mathrm{BCE}$ and its end as $539 \mathrm{BCE}$ (the date of the decree of Cyrus, King of Persia). These dates are in accordance with the first exile and the official freedom declaration for the return. The second view is that the exile would begin in $586 \mathrm{BCE}$ and end in 516 BCE with the dedication of the second temple. Dillard (ibid:301) conjectures that 'seventy' was not meant as a literal number. Meyers and Meyers (1987:388-389) propound the understanding that the 70 years started in $586 \mathrm{BCE}$ and ended in 516 BCE. The book of Zechariah 7:5, on which Meyers and Meyers ( $i b i d$ ) comment, refers to the 70 years as past time and not ending time. The 70 years was not about the destruction and dedication of the temple, but the exile (586-538 BCE) to Babylon.

The exile of Judah began in 586 BCE and ended in 538 BCE. The exile lasted for about 48 or 59 years, depending on the perception of the commencement date of the exile. The prophecy of 70 years was not precisely fulfilled and the Bible writers knew it, but they were writing theology as opposed to history. The story begins with the Pentateuch and ends with post-exilic Bible authors that reflect on the causes and effects of the exile.

\section{Total destruction}

The impression of the total destruction of Judah is not substantiated by either other historical sources or the Bible itself. The actual place concerned was Jerusalem. Lipschits (2005) opines:

2 Kings 25:11 implies that the entire population of Jerusalem was deported. This fits the remainder of the context, which deals only with the destruction of the city; there is no reference to other parts of the kingdom. (p. 83) 
Nevins (2006) refers to Jeremiah 44:2, 6 and 22, which present the destruction of Jerusalem to have resulted in desolation throughout the land of Judah. He (Nevins ibid:14) suggests that the texts are of late composition - after the exile had ended. The texts are contrasted with the picture one gets from Gedaliah, who simply tells the people to 'settle in the towns you have occupied'.

In essence, the reference to total destruction may relatively apply to the city of Jerusalem. If the word Judah is used when writing about Jerusalem, the meaning cannot be literal, but rather figurative in the light of Jerusalem being the capital city of Judah at that time. If Jerusalem had not been a capital city, the word Jerusalem would not have been used interchangeably with the word Judah. The same applies to the empires of Babylon and Rome being referred to as kingdoms, whilst they were not countries but simply cities. The names Babylon and Babylonia or Mesopotamia are used interchangeably to refer to the Neo-Babylonian kingdom. The actual name for the Roman Empire would be the 'Italian Empire', but it is commonly called 'Rome', as it was called then and even in our days. The name of the capital of Persia, 'Ecbatana', is seemingly not used interchangeably with Persia, because it was situated in the territory of Media and it had been the capital of Media before it was seized by Persia. Jerusalem was a city that could be regarded as Judah in a similar vein, since what happened in the city affected the whole nation of Judah.

\section{Legitimacy}

The aspect of legitimacy is of pivotal significance in the debate of the impact of the Babylonian exile on Judah. In Judah, Jeremiah's prophetic ministry was disregarded all the time until the prophet was taken to Egypt after Gedaliah's murder - thus leaving no legitimacy in Judah throughout the exile period. Ezekiel and Daniel played a noteworthy prophetic role in Babylon. Yates (2006:14-15) observes that the remnant Judeans and the Judeans in Egypt or in diaspora were not given any hope of restoration during the exilic period. The simple fact is that all civil and cultic legitimacy had been taken into exile.

Bigger (1994:236-237) states: 'Although misleading historically, the idea of a national exile is an important part of the Chronicler's presentation and must be recognised as such.' The writer (Bigger ibid:237) asserts: 'So for the Chronicler all the true community were taken into exile, and all were eager to return at the first opportunity.' 2 Chronicles 36:20 indicates that after the destruction of the temple and palaces, the remnant Jews of Jerusalem were taken to Babylon, and 2 Kings 25:18-21 reports the execution of some civil and cultic elite that were in Jerusalem in 586 BCE.

Noth (1959) comments about the Chronicler's perception of Judah and unequivocally states:

For him the legitimate line of Israel's history was represented by the Judeans who had been deported to Babylon, many of whom had to return to the homeland if the restoration of the temple was to be feasible. (p. 307)
Thiessen (2009:66) argues about the matter of legitimacy as a doctrinal matter and says that immediately after the exile returnees were the residue of Israel. Thiessen (2009:66) continues to say that residents in the land were regarded as foreigners, despite their religious identity and faithfulness to God. Cataldo (2010:55) comments on prophetic perspective and refers to the 'Golah' people that upheld the idea that eventually they would be the 'seed of life' to save the nation of Israel.

Of the people that remained, it could be said that only a small 'quantity' remained, but all 'quality' was gone or exiled. Bedford (2002:158) considers the post-exilic leaders of Judah against their exilic background and asserts that the remnant acknowledged their legitimacy in leadership. All what was left in Judah or Jerusalem was an impotent existence of Judeans who could not make a difference at all. All legitimacy was gone - either to Babylon or to other states surrounding Judah. The attempt to advocate the Judeans that remained in Judah during the exile is basically a futile exercise since they did not contend with the returnees' claims of legitimacy in the cultic functions. The Bible (a theological book) would probably not omit revelations of God that occurred in Judah during the exile. Therefore, in the absence of any religious matters to be recorded, it cannot be claimed that Judah continued with normal life during the exile.

\section{Myth tag}

Some scholars declare that the notion of the desolation or emptiness of the land due to the Babylonian exile is a myth, probably because of reasoning from a literal point of view. Coogan (2006:382) says: 'The exiles seem to have created the notion of an "empty land" a land devoid of inhabitants, which some modern scholars have adopted.' Guillaume (2005:91) regards the so-called 'Exile-Return' as a myth and further indicates that some deported families came back to 'colonize Judaea during the Persian period by excluding the vast majority of the inhabitants of the area from key positions in the temple and the administration'. The author emphatically postulates that " $[t]$ he term "exile" should be excluded from historical literature and replaced by the more neutral "deportation"' (Guillaume ibid:91). Guillaume (ibid:92) considers the emigration to Egypt of all Judeans, even from Benjamin territory, and says that it 'is also dubious; the land was not empty'. Davies (1999) argues that the exile was a removal of people out of Judah and back, and thus restoration of what had been disrupted. Davies (ibid:84) continues to assert: 'In that respect the exile is the central myth of the biblical account of the past.' Barstad (1996:78) argues that biblical authors have shown no intension of writing about the Judeans that remained in Judah during the exile, and therefore their writings 'should be regarded as mythical rather than historical'.

Truly, from a literal, quantitative and statistical point of view, neither Judah nor Jerusalem was devoid of residents. However, all that represented Judah was outside Judah and the elite had to return for anything significant to happen. The 
key people had gone into exile or had migrated elsewhere, leaving the leadership void. The exile of Judah may not be regarded as a myth, because it is not about the entire population of Judah per se, but rather about the existence of inhabitants of Judah leading a distinct divine prescribed Judean life. The influence of infiltrators almost obliterated all signs or epitome of Yahwism. When the aristocracy that led Judean lifestyle was exiled and some fled to neighbouring states, the essence of Judean lifestyle disintegrated and faded away in Judah. Judaism was only born in Babylon and was introduced into Judah by the returnees, who found syncretism to be rampant and at its pinnacle of existence in Judah.

\section{Summary}

During the time of Assyrian domination in Palestine and Syria, Judah was not unscathed. The loss of some territory prompted Judah to make an effort to exploit diplomatic ties with other states or countries. The schemes of diplomatic ties that ensued after the death of King Josiah set Judah up for disaster. After the rebellion of Zedekiah, the last king of Judah, Jerusalem, including the temple, was destroyed and skilled persons and warriors were exiled, as in earlier deportations. The Gedaliah governance structure, which was the spark of Judean survival as a state or a political entity, came to an end with the assassination of Gedaliah. Thus, the Judah state became an obsolete entity, probably attached to the Samaritan vassal governance structure or province. The limbo status of Judah was gradually obliterated by the infiltration of persons from neighbouring states that became mixed with the remnant by intermarriages.

Almost nothing is known about the lifestyle of the remnant, except that syncretism became one of the normal characteristics of their religion. When Babylon eventually fell, only the religious aspect of Judean identity was permitted to be restored and not the political independence, even though Judah became a province once again - to the dislike of Samaria. The returnees, who came to rebuild the temple and the city as a whole, did not recognise the remnant Judeans. The actual remnant, though corrupted and diluted, did not resist the reconstruction projects of the returnees, except for the Samaritans who wished to remain a province combined with the Judean territory. Fortunately, it was not a nonJew who wrote about the desolation of Judah, and no clear objection has been clearly heard from those who remained in Judah during the exile.

\section{Conclusion}

The fall of Assyria signalled the fall of Jerusalem, which was tantamount to the fall of Judah. From Josiah to Zedekiah, the last king of Judah, it was difficult for Judah to make good decisions with regard to the precarious international affairs of the time. Ultimately, Jerusalem, the capital city of Judah, was destroyed - unlike the rest of the states in Palestine and Syria. Judah was emptied of political and cultic personnel, because of its incessant recalcitrance. The understanding of the emptiness of Judah ought to be comprehended metaphorically or figuratively, and not literally. The emptiness expressed in Jewish literature was more about the interpretation of the meaning of the exile as opposed to statistical facts.

\section{Acknowledgements Competing interests}

The author declares that he has no financial or personal relationship(s) that may have inappropriately influenced him in writing this article.

\section{References}

Ahlström, G.W., 1994, The history of Ancient Palestine, Fortress, Minneapolis. Anstey, M., 1973, Chronology of the Old Testament, Kregel, Grand Rapids.

Baker, D.W., 1996a, 'Jehoahaz', in I.H. Marshall, A.R. Millard, J.I. Packer \& D.J. Wiseman (eds.), The New Bible Dictionary, InterVarsity Press, Leicester, 3rd edn., p. 545.

Baker, D.W., 1996b, 'Zedekiah', in I.H. Marshall, A.R. Millard, J.I. Packer \& D.J. Wiseman (eds.), The New Bible Dictionary, InterVarsity Press, Leicester, 3rd edn., pp. 12671268.

Barstad, H.M., 1996, The myth of the empty land, Scandinavian University Press, Oslo. Bedford, P.R., 2002, 'Diaspora: Homeland relations in Ezra-Nehemiah', Vetus Testamentum 52(2), 147-165. http://dx.doi.org/10.1163/156853302760013820

Beek, M.A., 1963, A short history of Israel, Hodder \& Stoughton, London.

Berquist, J.L., 2008, 'Spaces of Jerusalem', in J.L. Berquist \& V.C. Camp (eds.) Constructions of space II: The Biblical city and other imagined spaces, pp. 40-52, T\&T Clark, New York.

Betlyon, J.W., 2005, 'A people transformed: Palestine in the Persian period', Near Eastern archaeology 68(1-2), 4-58.

Bigger, S. (ed.), 1994, Creating the Old Testament: The emergence of the Hebrew Bible, Blackwell, Oxford

Bright, J., 1972, A history of Israel, SCM Press, London.

Bruce, F.F., 1997, Israel and the nations: The history of Israel from the exodus to the fall of the second temple, InterVarsity Press, Downers Grove.

Bullock, C.H., 2003, 'History and theology: The tale of two histories', in D. Howard \& M.A. Grisanti (eds.), Giving the sense: Understanding and using Old Testament historical texts, pp. 97-111, Apollos, Grand Rapids.

Cataldo, J.W., 2010, 'Whispered utopia: Dreams, agendas, and theocratic aspirations in Yehud', Scandinavian Journal of the Old Testament 24(1), 53-70. http://dx.doi. org/10.1080/09018328.2010.491602

Coogan, M.D., 2006, The Old Testament: A historical and literary introduction to the Hebrew Scriptures, Oxford University Press, New York.

Davies, P.R., 1999, In search of Ancient Israel, Sheffield Academic Press, Sheffield.

Davies, P.R., 2007, The origins of Biblical Israel, T\&T Clark, London.

Dillard, R.B., 1987, 2 Chronicles, Word Books, Waco. (Word Biblical Commentary 15).

Edersheim, A., 1995, Bible history: Old Testament, Hendrickson, Peabody.

Finegan, J., 1999, Handbook of Biblical chronology, Hendrickson, Peabody.

Fohrer, G., 1973, History of Israelite religion, SPCK, London.

Gertz, J.C., 2010, 'Military threat and the concept of exile in the book of Amos', in E. Ben Zvi \& C. Levin (eds.), The concept of exile in Ancient Israel and its historical contexts, pp. 11-26, De Gruyter, Berlin.

Grabbe, L.L., 2006, A history of the Jews and Judaism in the second temple period. Yehud: A history of the Persian province of Judah, vol. 1, T\&T Clark International, New York.

Guillaume, P., 2005, The Bible in its context, Naufal, Beirut.

Herrmann, P.R., 1981, A history of Israel in Old Testament times, Fortress Press, Philadelphia.

Isserlin, B.S.J., 2001, The Israelites, Fortress Press, Minneapolis.

Jensen, I.L., 1978, Jensen's survey of the Old Testament, Moody Press, Chicago.

Kaiser, W.C. Jr., 1998, A history of Israel: From the bronze age through the Jewish wars, Broadman \& Holman, Nashville.

Klein, R.W., 1979, Israel in exile: A theological interpretation, Fortress Press, Philadelphia.

Lipschits, O., 2005, The fall and rise of Jerusalem, Eisenbrauns, Winona Lake.

Meyers, C.L. \& Meyers, E.M., 1987, Haggai, Zechariah 1-8, Doubleday, New York. (Anchor Bible 25B).

Miller, J.M. \& Hayes, J.H., 1986, A history of Ancient Israel and Judah, Westminster Press, Philadelphia. 
Nevins, A.J., 2006, 'When was Solomon's temple burned down? Reassessing the evidence', Journal for the study of the Old Testament 31(1), 3-25. http://dx.doi. org/10.1177/0309089206068840

Noth, M., 1959, The history of Israel, Adam \& Charles Black, London.

Payne, D.F., 1996, 'Jerusalem', in I.H. Marshall, A.R. Millard, J.I. Packer \& D.J. Wiseman (eds.), The New Bible Dictionary, InterVarsity Press, Leicester, 3rd edn., pp. 557563.

Pfeiffer, C.F., 1962, Exile and return, Baker Book House, Grand Rapids.

Provan, I., Long, V.P. \& Longman III, T., 2003, A Biblical history of Israel, Westminster John Knox Press, Louisville.

Raabe, P.R., 1995, Obadiah, Doubleday, New York. (Anchor Bible 24D).

Renkema, J., 1998, Historical commentary on the Old Testament: Lamentations, Peeters, Leuven.

Roberts, J.J.M., 2002, The Bible and the Ancient Near East, Eisenbrauns, Winona Lake.

Rogerson, J.W. \& Davies, P.R., 1989, The Old Testament world, Prentice Hall, Englewood Cliffs.
Sacchi, P., 2000, The history of the second temple period, Sheffield Academic Press, Sheffield.

Scheffler, E., 2001, Politics in Ancient Israel, Biblia Publishers, Pretoria.

Soggin, J.A., 1993, An introduction to the history of Israel and Judah, Trinity Press International, Valley Forge.

Stern, E., 2004, 'The Babylonian gap: The archaeological reality', Journal for the study of the Old Testament 28(3), 273-277. http://dx.doi. org/10.1177/030908920402800302

Thiessen, M., 2009, 'The function of a conjunction: Inclusivist or exclusivist strategies in Ezra 6.19-21 and Nehemiah 10.29-30?', Journal for the study of the Old Testament 34(1), 63-79. http://dx.doi.org/10.1177/0309089209346350

Turner, G.A., 1973, Historical geography of the Holy Land, Baker Book House, Grand Rapids.

Wiseman, D.J., 1996, 'Assyria', in I.H. Marshall, A. R. Millard, J.I. Packer \& D.J. Wiseman (eds.), The New Bible Dictionary, InterVarsity Press, Leicester, 3rd edn., pp. 96100.

Yates, G., 2006, 'New exodus and no exodus in Jeremiah 26-45: Promise and warning to the exiles in Babylon', Tyndale Bulletin 57(1), 1-22. 